Vol. 16, $n^{\circ} 2 \mid 2012$

Varia

\title{
The Politics of Police History in Germany since the 1990s. A Participant Observation
}

Herbert Reinke

\section{(2) OpenEdition \\ Journals}

Electronic version

URL: http://journals.openedition.org/chs/1363

DOI: $10.4000 /$ chs. 1363

ISSN: 1663-4837

Publisher

Librairie Droz

Printed version

Date of publication: 1 December 2012

Number of pages: 99-106

ISBN: 978-2-600-01642-1

ISSN: $1422-0857$

\section{Electronic reference}

Herbert Reinke, «The Politics of Police History in Germany since the 1990s. A Participant

Observation », Crime, Histoire \& Sociétés / Crime, History \& Societies [Online], Vol. 16, n² | 2012, Online

since 01 December 2015, connection on 06 May 2019. URL : http://journals.openedition.org/chs/1363 ; DOI : 10.4000/chs.1363 


\title{
The Politics of Police History in Germany since the 1990s.
}

\author{
A Participant Observation
}

\author{
Herbert Reinke
}

\section{I - POLICE HISTORY IN GERMANY SINCE THE 1990s: GENERAL TRENDS}

For more than two decades, police history has occupied a significant position within German crime and criminal justice history. In July 2012, the $23^{\text {rd }}$ Kolloquium zur Polizeigeschichte - so the official German language title of this series founded in 1990 - took place in the Netherlands, and was organized by colleagues from the Dutch Police Academy ${ }^{1}$. Contrary to other themes within German crime and criminal justice history, which have experienced ups and downs of academic interests, police history has remained constantly at the heart of scholars' concerns, evidenced by a continuous output of publications and projects with opening of new approaches and themes. Yet, German police history is characterised not only by the extent of academic engagement, but also by the involvement of the German police in the research.

Traditionally, the engagement of the German police in police history has taken the form of commemorative writings and autobiographical accounts, often biased towards a positive and legitimising narrative, which generally did not meet the standards of scholarly research and style of presentation. However this has changed significantly in recent years: Several initiatives for research co-operation have improved the quality of research into police history in the German context by bringing together academic historians, communicating scholarly approaches to the police and practitioners, providing the 'inside' perspectives.

Looking at the chronology of German police history, one will notice that police history, i.e. historical research and writings about the police, had a late start in Germany in comparison with police history in other Western countries, in particular Britain and the United States. The 1990 'Conference of German Historians' marked the beginning of the 'new' police history in Germany; this was the first time that the annual meeting of German Historians had a session on police history ${ }^{2}$. Since then, police historians have covered extensively the general development and specific aspects of German policing since the beginning of the $19^{\text {th }}$ century. Nevertheless certain priorities have developed. ${ }^{3}$ During the 1990s, German police history elaborated interpretations of police developments during the long $19^{\text {th }}$ century, until the end of the First World War, while research on the police history of the

\footnotetext{
$1 \quad[$ https ://www.politieacademie.nl/kennisenonderzoek/Lectoraten/LectoraatPolitiegeschiedenis/Pages/ LectoraatPolitiegeschiedenis.aspx].

2 Lüdtke (1992); Reinke (1993).

3 Reinke (2009).
} 
Weimar Republic was limited and still remains understudied, at least compared to the attention given to other periods of German police history. Because of the specificities of German history during the $20^{\text {th }}$ century, with the Nazi regime from 1933 to 1945 and the communist regime in East Germany from 1945 to 1989, the impetus for researching the police forces of these regimes has been very strong and continues to be $\mathrm{so}^{4}$. As far as the Nazi regime is concerned, the focus in the 1990s was initially very much on the Gestapo, but this has shifted to the 'Ordnungspolizei' and its role in the atrocities during the Holocaust as well as its everyday practices during the Nazi era. Historical investigations into the police forces of the communist regime in East Germany show a different pattern. This research only set in after the fall of the communist regime in 1989 and has since focused more or less exclusively on the state security police (the Stasi) of the East German regime and only to a limited extent on ordinary policing and the institutions of the 'Volkspolizei'. At the same time, research on the history of policing in the Federal Republic has gained momentum, even if a number of unexplored fields still remain ${ }^{5}$.

During the early years of this 'new' German police history, another significant pattern evolved, namely the involvement of police practitioners in the development of police history and its research activities ${ }^{6}$. This engagement often took the form of joint historical enterprises between academic historians and professional police officers, who were interested in the history of their particular force. In practice this meant primarily the history of police forces in major German cities. One reason why the collaboration between historians and police tended to focus on big city police is the federalism which characterises the German political system and political culture. Given that political institutions and administrative units of the majority of 'Länder' (with the exception of Bavaria, Bremen and Hamburg) were established without precedent before 1945, big city police forces were particularly interesting because of their institutional continuities going back before 1945, carrying on uninterrupted beyond 1945, into the 1950s and right up to the present.

These joint enterprises set specific standards, which pertained to the majority of police history projects which actively involved both academic historians and police practitioners. Not only did the police finance much of this research, which was of course an important factor in getting projects off the ground, but the collaboration also served as a model and provided a framework for follow-up- projects. At the same time, the collaboration provided a forum in which the results of archival investigations could be discussed and evaluated jointly by the members of the respective police history groups; yet even more important was the unlimited access it provided to police documents, particularly recent material that was not yet transferred to the archives at the time of the investigations.

\section{II - POLICE HISTORY AND 'VERGANGENHEITSBEWÄLTIGUNG'}

The so-called 'Vergangenheitsbewältigung', i.e. the collective effort by Germans to come to terms with the Nazi past, is a prominent and permanent feature of public

Schulte (2009); Deutsche Hochschule der Polizei (2011).

Fürmetz, Reinke, Weinhauer (2001); Weinhauer (2003); Weinhauer, Requate, Haupt (2006).

In 1990, the Archiv für Polizeigeschichte was launched as a police history journal, covering the German-speaking countries. 
debates and political culture in Germany. The 'Vergangenheitsbewältigung' itself has become a topic of historical research and the literature on this phenomenon already fills the shelves of university libraries and preoccupies historical seminars. Coming to terms with the Nazi past has always been a complex issue in Germany ${ }^{7}$. Up to 1990s, calls for public engagement with 'Vergangenheitsbewältigung' still met resistance both from private companies, as well as state institutions, such as ministries and the police. These institutions were all very reluctant to deal with aspects of their own past and openly denied any need to deal with the history of the Nazi era. Denials typically took the form of pretending that no continuities existed between the Nazi era and Germany after 1945, or claiming that research had already been carried out internally in the institution, revealing nothing untoward. Such denials quite often related to particular individuals among the senior personnel within these institutions, whose personal history was intrinsically linked to the Nazi era. These individuals had either started their professional career under the Third Reich or had been socialized by more senior personnel with careers spanning the Nazi era. When these senior officials gradually retired or died, the institutions became more open to approach questions relating to the 'Vergangenheitsbewältigung', and prepared to deal with their institutional past.

A number of factors have motivated these institutions - or rather senior officials within the institutions - towards greater openness and engagement with research into past activities of their institution. These include organizational and political aspects as well as the need for 'positive publicity' ${ }^{8}$. In the first place, dealing with the historical past of an institution is increasingly seen as crucial for the development of a positive organisational culture and improved efficiency. Secondly, the German public in general recognises as positive any honest effort to deal with the Nazi past, and gives credit to those who are prepared to engage with 'Vergangenheitsbewältigung'. Thirdly, within many institutions of the Federal Republic, a self-understanding has evolved, which sees the development of the institutional infrastructure of the Federal Republic as part of the democratic success story of the Federal Republic. The successful democratisation of institutions is considered all the more laudable, given that it evolved against the background of a terrible past. That is why many of the research questions formulated in this context not only seek to identify scandalous continuities in personnel and practices beyond 1945, but also aim at demonstrating how successfully the respective institutions have moved towards democracy and 'Rechtsstaat' despite the heavy legacies of the Nazi past.

All these aspects are reflected in recent police history projects. The first two aspects pertain particularly to projects on big city police forces (see below), while the third aspect can be discerned in the motivations behind the support from federal government institutions for current research projects on policing: one project on the history of the Bundeskriminalamt was very much driven by the wish to describe the institution as a success story of organisational democratisation (see details below). For two other projects into the secret services (the "Bundesnachrichtendienst" and the "Bundesamt für den Verfassungsschutz"), which both started in 2011-2012, the main impetus can very probably can be linked to attempts by these institutions to get credit from the public for engaging in the 'Vergangenheitsbewältigung'. Similarly in 2011, the national German police college launched an exhibition on the history

Frei (1996).

$8 \quad$ Reinke (2009); Baumann, Stephan, Wagner (2012). 
of the German police during the Nazi period at the German Historical Museum in Berlin 9 .

\section{III - BIG CITY POLICE AND POLICE HISTORY}

The police was among the pioneering institutions, who engaged in researching their own history. The first co-operations with joint police history activities between university historians and members of urban police forces in West Germany were initiated already in the early 1980s. These co-operative projects were very much driven by the so-called 'critical' police officers, many of whom were members of the German police union, which saw research into police history as part of a police reform strategy. This strategy aimed at a more civilian, service orientated and self-reflecting police. Yet this push for reform became highly contested within a police arena where they did not find undivided acceptance among the majority of the police personnel. Some of these early police history projects came under attack from within the police, as certain individuals at the senior ranks of the police were not yet ready for critical views on the history of their force ${ }^{10}$. Only one of these projects, the one initiated by the Polizeipräsidium Düsseldorf, came to a positive outcome that resulted in a publication, which took into account what was, in those days, the common interpretations of police history, yet discussed aspects of police history in a very elaborate manner ${ }^{11}$. This Düsseldorf project prepared the ground for a permanent police history exhibition at the Düsseldorf police headquarters, which showed the role and the functions of the Düsseldorf police during the Nazi period.

Almost a decade later, during the 1990s, there was a revival of police history activities, involving big city police forces. Among these big city police histories, the most prominent was in many respects the one carried out under the auspices of the Cologne Police, which investigated policing in Cologne during the Nazi period. One major finding of the project on the Cologne police has been the documentation of how everyday policing was deeply and intensively involved in pursuing the racial policies of the Nazi regime ${ }^{12}$. Further projects on the police of major German cities during that period have confirmed these findings, demonstrating the participation of police forces in implementing the racial policies of the Nazi regime ${ }^{13}$. In addition, this research also showed the extent to which the 'Kriminalpolizei' had not only been a passive instrument but actively reinforced the racial policies of the regime. The Cologne police history project also generated educational material, to be used in schools ${ }^{14}$.

\section{IV - THE HISTORY PROJECT OF THE BUNDESKRIMINALAMT}

In 2007, the Federal Criminal Investigation Office, the Bundeskriminalamt (BKA), initiated a history project, with the purpose of studying the history of

\footnotetext{
Schulte (2009); Deutsche Hochschule der Polizei (2011).

10 Fangemann, Reifner, Steinborn (1987); Steinborn, Schanzenbach (2000).

11 Polizeipräsidium Düsseldorf (1983).

12 Buhlan, Jung (2000).

13 Goch (2005); Schlossmacher (2006); Dams, Dönecke, Köhler (2007).

14 Jung (2005).
} 
the BKA during the 1950s and 1960s, thereby questioning the extent to which continuities existed within the organisation: Indications of 'continuities' were established in two ways. The study aimed at identifying the members of the BKA in the 1950s and 1960s, who had also served in the security forces during the Nazi regime, and on that basis tried to calculate the proportion of employees from the security forces of the Nazi era among the total personnel of the BKA in the 1950s and 1960s. The second aspect of 'continuity' aimed at establishing what impact, if any, these characters among the BKA-personnel had on the working methods and practices of the organisation. The aim was to establish the extent to which the work of the BKA was influenced or shaped by these people.

Already in the 1990s, there had been attempts to answer some of these research questions. At that time, a former member of the BKA embarked on a critical investigation into the past of the organisation, and published a highly sensationalist book about the BKA ${ }^{15}$. He revealed the Nazi past of senior officials and combined this with his own hypothesis that their continued presence in the BKA after 1945 might have prevented the organisation from seriously investigating right-wing political extremism ("being blind on the right eye"). This project met significant resistance from the BKA; it did not get political support, and it seems that access to documentary sources was blocked.

In 2007, the BKA itself launched its own initiative for a history of the organisation, and invited proposals for a historical research project. This eventually led to the establishment of a research group comprising Imanuel Baumann, Andrej Stephan, Patrick Wagner, all from the University of Halle, and Herbert Reinke from the University of Wuppertal, who were charged with the task of researching the past of the BKA. Before embarking on the project, the research group and the BKA made an agreement on three principles for the investigations: Firstly, the specific research questions were to be - and were in effect - defined by the research group and not by the BKA. On the other hand, it was the BKA who determined the overall framing of the research - namely the Nazi legacies in the BKA during the 1950s and 1960s while abstaining from any involvement with the actual research process. Secondly, there were to be no limitations for the members of the research team on the use of available source material. Thirdly, all the document sources held by the BKA which the research team wanted to consult should be transferred to the Federal Archives once the research findings had been published. These principles were agreed upon in order to ensure the basic conditions for scholarly research, in particular to guarantee that the data of the research would be available for scholars to re-examine, with open access to all the sources used by the research group. Restriction on the free access to sources should only apply when personal data and information regarding other persons appeared in the respective sources, notably when using the personnel files of individual BKA members.

The BKA organized four colloquia, with two at a very early stage of the project. The purpose of the first colloquium was to introduce the research team to the BKA itself and to generate support among the BKA personnel; the second colloquium sought to publicise the launching of the project to a wider scholarly audience and to the general public. Towards the end of the project the team presented their findings to the same audiences. The results of the project have now been published in two

Schenk (2001). 
collective volumes, presenting the proceedings of the colloquia and a monograph, which includes the results of the research proper ${ }^{16}$.

A summary of the main conclusions of the research reveals a picture, which resembles what has been observed elsewhere about the legacies of the Nazi past within political institutions in the Federal Republic during the 1950s and 1960s: Among the members of the higher ranks of the BKA who were in active service by the end of the 1950s, 90 percent had held a position in the police during the Nazi period. Nonetheless the BKA did not refrain from employing them, even those officers who had been tried for war crimes in countries formerly under Nazi occupation. These observations do not differ very much from research findings into other public institutions during the early years of the Federal Republic: It is common wisdom among historians nowadays that the members of the so-called 'functional elites' (Funktionseliten) in the early Federal Republic had held similar positions during the Nazi period. More interesting were the observations made on the questions concerning the influence of these individuals on the practices of the BKA. The findings provide a highly differentiated picture: After 1945, and notably during the 1950s, the members of the BKA who had a past within the Nazi security police apparatus repeatedly sought to promote what, in their view, constituted efficient crime control policies, and which had been tried out during the Nazi regime. These included, in the first place, sending criminals into specific institutions of confinement, in the same way that criminals had been sent to concentration camps during the Nazi period. Secondly, they proposed targeting specific groups such as habitual criminals, gypsies etc.. Thirdly they demanded an autonomous and independent role for a centralized police within the criminal justice system of the Federal Republic. Nevertheless concentration camps, even masked as special institutions for the confinement of criminals, were no longer acceptable, and a centralized police resembled too much the Gestapo. On the other hand, the idea of targeting specific groups lingered on in the files of the BKA far into the 1990s. In that respect, blind spots remained in the BKA's own understanding of having successfully transformed itself in line with the democratic system of the Federal Republic.

\section{V - THE HISTORY OF THE POLICE FORCES OF THE GERMAN DEMOCRATIC REPUBLIC: ANOTHER MODE OF 'VERGANGENHEITSBEWÄLTIGUNG'?}

Since the end of the German Democratic Republic and the merging of the GDR with the Federal Republic, the potential emerged for investigating further aspects of police history. The police and scholarly researchers have seized this opportunity in a variety of ways. The communist German Democratic Republic - just like other communist regimes in Central, Eastern and South-Eastern Europe - build up a vast police apparatus, comprising the 'Volkspolizei' as the main police force, and the state security police, the 'Staatssicherheit' (Stasi). The 'Volkspolizei' covered not only 'ordinary' policed functions (those generally fulfilled by police forces in noncommunist countries) such as law and order maintenance and traffic control. This

16 These volumes are now available as pdf from the project site of the Bundeskriminalamt [http://www. bka.de/DE/Publikationen/BKA-Historie/bkaHistorie_node.html?_nnn=true]. 
police force was also deeply embedded into the structures and strategies responsible for sustaining the communist regime, including the repressive activities against those who applied for permission to leave the GDR in order to live in the Federal Republic. As in other communist countries, the prisons fell within the remit of the 'Volkspolizei', which meant that the prison personnel in the former GDR consisted of policemen. All this indicates that the 'Volkspolizei', alongside the state security service, was equally involved in the repressive strategies of the communist regime.

The East German state security police was dissolved already during the final months of the GDR, its members dismissed and its files transferred into a special archive open for research purposes and for private investigations. After the German reunification, the members of the former 'Volkspolizei' formed the basis for the police forces in the new federal states which had previously been part of the GDR. Before becoming the 'new' police of the 'new' Länder in the enlarged Federal Republic, the personnel from the former 'Volkspolizei' had to pass through screening procedures: Those who had cooperated with the state security police or held positions at the upper ranks of the communist party were dismissed. Since then, researchers have investigated these two police forces in very dissimilar ways: The state security police became the object of much research immediately after its dissolution, and the literature on this organisation already fills the shelves of libraries. The 'Volkspolizei', by contrast, has received little attention from researchers until recently, and the continued presence of former 'Volkspolizei' members within the police of the Federal Republic does not provide an easy historiographical framework, which could facilitate the writing of the history of the 'Volkspolizei'. This history will most probably be written with considerable delay, similar to the delay experienced in the writing on the police in the 'old' Federal Republic.

Herbert Reinke University of Wuppertal reinke@uni-wuppertal.de

\section{REFERENCES}

Baumann, I., Reinke, H., Stephan, A., Wagner, P., Schatten der Vergangenheit - Das BKA und seine Gründungsgeneration in der frühen Bundesrepublik, Köln, Luchterhand, 2011.

Baumann, I., Stephan, A., Wagner, P., '(Um-) Wege in den Rechtsstaat, Das Bundeskriminalamt und die NS-Vergangenheit seiner Gründungsgeneration', Zeitgeschichte online, 2012 (online journal).

Buhlan, H., Jung, W. (Eds), Wessen Freund und wessen Helfer? Die Kölner Polizei im Nationalsozialismus, Köln, Emons Verlag, 2000.

Bundeskriminalamt (ed.), Das Bundeskriminalamt stellt sich seiner Geschichte. Dokumentation einer Kolloquienreihe, Köln, Luchterhand, 2009.

Bundeskriminalamt (ed.), Der Nationalsozialismus und die Geschichte des BKA-Spurensuche in eigener Sache, Köln, Luchterhand, 2011.

Dams, C., Dönecke, K., Köhler, Th. (Eds), "Dienst am Volk” ? Düsseldorfer Polizisten zwischen Demokratie und Diktatur, Frankfurt/Main, Verlag für Polizeiwissenschaft, 2007.

Deutsche Hochschule der Polizei (Eds), Ordnung und Vernichtung. Die Polizei im NS-Staat, Dresden, Sandstein Verlag, 2011. 
Fangemann, H., Reifner, U., Steinborn, N., “Parteisoldaten”. Die Hamburger Polizei im “3. Reich”, Hamburg, VSA-Verlag, 1987.

Frei, N., Vergangenheitspolitik. Die Anfänge der Bundesrepublik und die NS-Vergangenheit, München, Verlag C.H. Beck, 1996.

Fürmetz, G., Reinke, H., Weinhauer, K. (Eds), Nachkriegspolizei. Sicherheit und Ordnung in Ost- und Westdeutschland 1945-1969, Hamburg, Ergebnisse Verlag, 2001.

Goch, S. (ed.), Städtische Gesellschaft und Polizei. Beiträge zur Sozialgeschichte der Polizei in Gelsenkirchen, Essen, Klartext Verlag, 2005.

Jung, W. (ed.), Wessen Freund und wessen Helfer? Didaktische Materialien zur Kölner Polizei im Nationalsozialismus, Köln, NS-Dokumentationszentrum der Stadt Köln, 2005.

Lüdtke, A. (ed.), 'Sicherheit' und 'Wohlfahrt'. Polizei, Gesellschaft und Herrschaft im 19. und 20. Jahrhundert, Frankfurt/Main, Suhrkamp Verlag, 1992.

Polizeipräsidium Düsseldorf (ed.), 50 Jahre Polizeipräsidium Düsseldorf, Düsseldorf, 1983.

Reinke, H. (ed.), “... nur für die Sicherheit da...” ? Zur Geschichte der Polizei im 19. und 20. Jahrhundert, Frankfurt/Main, Campus Verlag, 1993.

Reinke, H., "Restauration" oder "Ein neuer Anfang": Zur Polizeigeschichte und geschichtsschreibung des "Dritten Reiches" und der Bundesrepublik, in Bundeskriminalamt (ed.), Das Bundeskriminalamt stellt sich seiner Geschichte. Dokumentation einer Kolloquienreihe, Köln, Luchterhand, 2009, pp. 143-159.

Schenk, D., Auf dem rechten Auge blind. Die braunen Wurzeln des BKA, Köln, Verlag Kiepenheuer und Witsch, 2001.

Schlossmacher, N. (ed.), "Kurzerhand die Farbe gewechselt": Die Bonner Polizei im Nationalsozialismus, Bonn, Veröffentlichungen des Stadtarchivs Bonn, 2006.

Schulte, W. (ed.), Die Polizei im NS-Staat. Beiträge eines internationalen Symposiums an der Deutschen Hochschule der Polizei, Frankfurt/Main, Verlag für Polizeiwissenschaft, 2009.

Steinborn, N., Schanzenbach, K., Die Hamburger Polizei nach 1945 - Ein Neuanfang, der keiner war, Hamburg, Verlag Heiner Biller, 2000.

Weinhauer, K., Schutzpolizei in der Bundesrepublik. Zwischen Bürgerkrieg und Innerer Sicherheit: Die turbulenten sechziger Jahre, Paderborn, Ferdinand Schöningh, 2003.

Weinhauer, K., Requate, J., Haupt, H.-G. (Eds), Terrorismus in der Bundesrepublik. Medien, Staat und Subkulturen in den 1970er Jahren, Frankfurt/Main, Campus Verlag, 2006.

\section{German Police History Sites}

Bundeskriminalamt:

[http ://www.bka.de/DE/Publikationen/BKA-Historie/bkaHistorie_node.html?_nnn=true].

Bundesnachrichtendienst (Federal External Secret Service):

[http ://www.uhk-bnd.de/].

Villa ten Hompel (History of the Geman Ordnungspolizei'-memorial) :

[http ://www.muenster.de/stadt/villa-ten-hompel/].

Düsseldorf police history (Nazi period):

[http ://www.geschichte-am-jürgensplatz.de/index.php ?option=com_content\&view=article\& $\mathrm{id}=51 \&$ Itemid $=66 \& 2 \mathrm{c} 96 \mathrm{~d} 15 \mathrm{a} 6 \mathrm{ea} 21 \mathrm{c} 715 \mathrm{f} 281 \mathrm{cf} 2 \mathrm{be} 444292=4 \mathrm{db} 3565306 \mathrm{c} 6828847 \mathrm{a} 83 \mathrm{e} 4$ a8490eb2f].

Bundesbeauftragter für die Unterlagen des Staatssicherheitsdienstes der ehemaligen Deutschen Republik (Federal Commissioner for the Archives of the State Security of the former German Democratic Republic:

[http ://www.bstu.bund.de/DE/Home/home_node.html]. 